\title{
Perencanaan Penanganan Kawasan Permukiman Kumuh (Studi Penentuan Kawasan Prioritas untuk Peningkatan Kualitas Infrastruktur pada Kawasan Permukiman Kumuh di Kota Malang)
}

\author{
Donny Wahyu Wijaya ${ }^{\text {a }}$ * \\ ${ }^{a}$ Bappeda Kota Malang, Jawa Timur, Indonesia
}

\section{INFORMASI ARTIKEL}

\section{Article history:}

Dikirim tanggal: 05 Februari 2016

Revisi pertama tanggal: 23 Maret 2016

Diterima tanggal: 23 Mei 2016

Tersedia online tanggal: 11 Juni 2016

Keywords: planning, slum areas infrastructure, priority areas

\section{ABSTRACT}

Regions urban slums emerge as one of the impact of the lack of success of development in urban settlements and urban land constraints. This study aims is to identify the characteristics of a slum area, determine the priority areas for improving the quality of infrastructure in the slum areas, and provide recommendations on the strategy of improving the quality of infrastructure slum areas in Malang Municipal. The results showed that based on the assessment of the areas where research was conducted, there are 11 (eleven) classification of slum areas and five (5) priority areas for improving the quality of infrastructure in slum areas. From the result of the SWOT analysis, the recommendation strategy for improving the quality of infrastructure in the slum areas, are: planning improvement of the quality of infrastructure in the slum areas in a comprehensive manner; improve the coordination and synchronization of programs and activities; involve the community in the planning process; improve coordination and synergies with relevant institutions in the spatial use in the city area along in the border areas and riverbanks; increase socialization as an effort to increase understanding and awareness for the public; and to seek opportunities for cooperation with the private sector in improving the quality of infrastructure of the slums.

\section{INTISARI}

Kawasan permukiman kumuh perkotaan timbul sebagai salah satu dampak kurang berhasilnya pembangunan permukiman di perkotaan dan keterbatasan lahan perkotaan. Penelitian ini bertujuan untuk mengidentifikasi karakteristik kawasan permukiman kumuh, menentukan kawasan prioritas untuk peningkatan kualitas infrastruktur pada kawasan permukiman kumuh, dan memberikan rekomendasi strategi peningkatan kualitas infrastruktur pada kawasan permukiman kumuh di Kota Malang. Hasil penelitian ini menunjukkan bahwa berdasarkan penilaian terhadap kawasan-kawasan yang menjadi lokasi penelitian ini, terdapat 11 (sebelas) klasifikasi kawasan permukiman kumuh dan 5 (lima) kawasan prioritas untuk peningkatan kualitas infrastruktur kawasan permukiman kumuh. Dari hasil analisis SWOT direkomendasikan strategi peningkatan kualitas infrastruktur pada kawasan permukiman kumuh, yaitu: penyusunan rencana peningkatan kualitas infrastruktur pada kawasan permukiman kumuh secara komprehensif; meningkatkan koordinasi dan sinkronisasi program dan kegiatan; melibatkan masyarakat dalam proses penyusunan rencana; meningkatkan koordinasi dan sinergi dengan instansi terkait dalam pemanfaatan ruang wilayah kota serta pada kawasan sempadan dan bantaran; meningkatkan sosialisasi sebagai upaya peningkatan pemahaman dan kesadaran bagi masyarakat; dan mengupayakan peluang kerjasama dengan serta sektor swasta dalam peningkatan kualitas infrastruktur permukiman kumuh. 


\section{Pendahuluan}

Sebagaimana diamanatkan dalam Perubahan Kedua Undang-Undang Dasar Negara Republik Indonesia Tahun 1945, yang ditetapkan pada tanggal 18 Agustus Tahun 2000, dalam Pasal $28 \mathrm{H}$ ayat (1) disebutkan bahwa: "Setiap orang berhak hidup sejahtera lahir dan batin, bertempat tinggal, dan mendapatkan lingkungan yang baik dan sehat serta memperoleh pelayanan kesehatan". Hal ini dapat dimaknai bahwa perumahan dan kawasan pemukiman yang baik dan sehat merupakan hak dasar bagi setiap warga negara yang harus dijamin oleh negara dan menjadi tanggung jawab negara. Karena merupakan hak dasar bagi setiap warga negara, maka hal ini menjadi hak bagi warga negara, baik yang telah mampu memenuhi kebutuhan tersebut sendiri, maupun bagi warga negara yang belum mampu memenuhinya sendiri, sehingga menjadi kewajiban negara untuk memenuhi kebutuhan tersebut dan menciptakan kesejahteraan bagi seluruh warga negara.

Belum berhasilnya pembangunan permukiman di perkotaan erat kaitannya dengan persoalan urbanisasi, keterbatasan lahan perkotaan dan kurang tepatnya program-program pembangunan kota, yang merupakan penyebab timbulnya kawasan permukiman kumuh perkotaan. Peraturan Pemerintah Republik Indonesia Nomor 88 Tahun 2014 tentang Pembinaan Penyelenggaraan Perumahan dan Kawasan Permukiman, merupakan upaya yang dilakukan pemerintah untuk mewujudkan tercapainya tujuan penyelenggaraan perumahan dan kawasan permukiman, termasuk pencegahan dan peningkatan kualitas terhadap perumahan kumuh dan permukiman kumuh. dapat dimanfaatkan untuk kepentingan bersama.

Kawasan permukiman kumuh seringkali identik dengan keberadaan penduduk miskin. Persepsi ini tidak selalu benar karena di dalam kawasan permukiman kumuh juga terdapat penduduk yang tidak termasuk kategori miskin. Hal ini ditandai dengan kondisi rumah dan fasilitas yang mereka miliki dikawasan permukiman kumuh tersebut. Ada dua hal yang mencirikan kawasan tersebut dikatakan kumuh yaitu, pertama; kawasan tersebut tidak atau kurang terlayani dengan infrastruktur pendukung kawasan seperti jaringan jalan, drainase, saluran limbah dan lain-lain, sehingga kawasan tersebut cenderung mengalami degradasi. Kedua; hunian di kawasan tersebut secara kasat mata terlihat tidak layak huni yang ditandai dengan kurangnya ventilasi maupun pencahayaan, disamping mutu material bangunannya yang tidak layak dijadikan sebagai bahan bangunan untuk sebuah hunian.

Kajian tentang permukiman kumuh pada umumnya mencakup tiga segi, pertama kondisi fisiknya, kedua kondisi sosial ekonomi budaya komunitas yang bermukim di pemukiman tersebut, dan ketiga dampak oleh kedua kondisi tersebut. Kondisi fisik antara lain tampak dari kondisi bangunan yang sangat rapat dengan kualitas konstruksi rendah, jaringan jalan tidak berpola dan kondisi perkerasan yang kurang baik, sanitasi umum dan saluran drainase tidak berfungsi dengan baik, serta pengelolaan sampah yang kurang baik. Sedangkan kondisi sosial ekonomi masyarakat yang tinggal dikawasan pemukiman kumuh antara lain mencakup tingkat pendapatan rendah, norma sosial yang longgar, budaya kemiskinan yang mewarnai kehidupannya yang antara lain tampak dari sikap dan perilaku yang apatis. Kondisi tersebut sering juga mengakibatkan kondisi kesehatan yang buruk, sumber pencemaran, sumber penyebaran penyakit dan perilaku menyimpang, yang berdampak pada kehidupan kota keseluruhannya. Oleh karena itu kawasan pemukiman kumuh dianggap sebagai permasalahan kota yang harus diatasi.

Akar masalah permukiman kumuh lebih bersifat kompleks yaitu karena:

1) Pembiaran (neglegiance) berkembangnya ruangruang marjinal perkotaan;

2) Lemahnya pengelolaan kota;

3) Belum adanya pengenalan terhadap kebutuhan (housing need assessment) dan persediaan rumah (housing stock evaluation) secara utuh dan partisipatif; dan

4) Belum adanya pengembangan sistem penyediaan perumahan secara utuh (housing delivery system).

Pemerintah telah menetapkan Undang - Undang Nomor 1 Tahun 2011 tentang Perumahan dan Kawasan Permukiman, yang merupakan revisi terhadap UndangUndang Nomor 4 Tahun 1992 tentang Perumahan. Secara umum, Undang-Undang ini merupakan wujud perhatian pemerintah terhadap penanganan perumahan kumuh dan permukiman kumuh. Dalam Pasal 1 poin (1) UndangUndang Nomor 1 Tahun 2011, dinyatakan bahwa perumahan dan kawasan permukiman adalah satu kesatuan sistem yang terdiri atas pembinaan, penyelenggaraan perumahan, penyelenggaraan kawasan permukiman, pemeliharaan dan perbaikan, pencegahan dan peningkatan kualitas terhadap perumahan kumuh dan permukiman kumuh, penyediaan tanah, pendanaan dan sistem pembiayaan, serta peran masyarakat.

Undang-Undang tersebut menyebutkan secara eksplisit bahwa salah satu ruang lingkup penyelenggaraan Perumahan dan Kawasan Permukiman adalah pencegahan dan peningkatan kualitas terhadap perumahan kumuh dan permukiman kumuh. Hal ini yang kemudian diterjemahkan dalam bentuk kebijakan, strategi dan program oleh berbagai institusi pemerintah yang bertanggungjawab.

Untuk dapat melaksanakan ketentuan dalam Undang-Undang Nomor 1 Tahun 2011 tentang 
Perumahan dan Kawasan Permukiman ini, telah ditetapkan Peraturan Pemerintah Republik Indonesia Nomor 88 Tahun 2014 tentang Pembinaan Penyelenggaraan Perumahan dan Kawasan Permukiman. Pembinaan Penyelenggaraan Perumahan dan Kawasan Permukiman merupakan upaya yang dilakukan untuk mewujudkan tercapainya tujuan penyelenggaraan perumahan dan kawasan permukiman. Pembinaan dilakukan dalam lingkup perencanaan, pengaturan, pengendalian, dan pengawasan. Tanggung jawab pemerintah dilakukan melalui koordinasi; sosialisasi peraturan perundang-undangan; bimbingan, supervisi dan konsultasi; pendidikan dan pelatihan; penelitian dan pengembangan; pendampingan dan pemberdayaan; serta pengembangan sistem informasi dan komunikasi.

Kota Malang sebagai salah satu kota di Indonesia yang memiliki pertumbuhan dan perkembangan kota yang sangat cepat baik dalam pertumbuhan fisik maupun ekonomi. Hal tersebut menjadi daya tarik bagi para pendatang sebagai kaum urban untuk mengadu nasib dalam mencari nafkah di Kota Malang yang menyebabkan semakin padatnya jumlah penduduk. Sayangnya kedatangan para pengadu nasib tidak selalu diimbangi dengan pengetahuan dan pendidikan yang memadai, sehingga timbul kelompok masyarakat kurang mampu berpenghasilan rendah. Keadaan tersebut diperburuk dengan terbatasnya lahan sebagai wadah kegiatan hidup dan tempat tinggal, yang mengakibatkan tingginya harga tanah dan rumah di Kota Malang. Hal ini menimbulkan daerah-daerah dapat diidentifikasikan sebagai suatu daerah yang padat penduduk, dengan tingkat ekonomi yang rendah sehingga tidak memenuhi persyaratan standar hidup layak huni dan sehat, misalnya tersedianya layanan air bersih dan sanitasi, yang merupakan ciri dari kekumuhan.

Sebagaimana visi Kota Malang yang ingin dicapai didalam Rencana Pembangunan Jangka Menengah Daerah (RPJMD) Kota Malang Tahun 2013-2018, yaitu "Terwujudnya Kota Malang Sebagai Kota Bermartabat", khususnya dalam upaya mewujudkan misi kesembilan, yaitu "Mengembangkan Sistem Transportasi Terpadu Dan Infrastruktur Yang Nyaman Untuk Meningkatkan Kualitas Hidup Masyarakat" (Bappeda, 2014), maka adanya kawasan permukiman kumuh pada ruang kota ini menjadi pekerjaan rumah yang besar bagi Pemerintah Kota Malang untuk menanganinya.

Sebagai upaya Pemerintah Kota Malang untuk menangani kawasan permukiman kumuh yang ada, Pemerintah Kota Malang telah menetapkan Peraturan Daerah Nomor 12 Tahun 2014 tentang Rencana Pembangunan dan Pengembangan Perumahan dan Kawasan Permukiman (RP3KP) Kota Malang. Di dalam Bagian Kedua RP3KP tentang Misi Pembangunan dan Pengembangan Perumahan dan Kawasan Permukiman, pada pasal 12 (c) menyatakan komitmen Pemerintah Kota Malang yaitu: Mewujudkan peningkatan kualitas permukiman kumuh dan di Kota Malang.

Menindaklanjuti Peraturan Daerah tersebut diatas, Pemerintah Kota Malang menetapkan luasan kawasan kumuh melalui Keputusan Walikota Malang Nomor 188.45/ 86 /35.73.112/2015 tentang Penetapan Lingkungan Perumahan dan Permukiman Kumuh, dimana luasan kawasan kumuh di Kota Malang adalah seluas 608,60 Ha yang meliputi 29 Kelurahan pada 5 Kecamatan di Kota Malang.

Pemerintah Kota Malang belum memiliki perencanaan penanganan kawasan kumuh yang komprehensif, sehingga dalam implementasinya penentuan prioritas penanganannya dilakukan secara sporadis. Meskipun telah memiliki Rencana Pembangunan dan Pengembangan Kawasan Permukiman (RP2KP) maupun Strategi Pembangungan dan Pengembangan Infrastruktur Permukiman (SPPIP), perencanaannya belum terintegrasi dengan kawasan permukiman kumuh yang telah ditetapkan dan belum memberikan prioritas penanganan bagi kawasan permukiman kumuh tersebut. Penentuan kawasan yang akan dilakukan penanganan masih dilakukan dengan pendekatan top-down, baik dari Pemerintah Pusat (melalui kegiatan pilot project) maupun dari kebijakan Pemerintah Daerah sendiri. Penentuan prioritas pada kawasan-kawasan yang telah ditetapkan sebagai kawasan kumuh penting untuk dilakukan, karena dengan menyusun suatu prioritas, maka segala sumber daya yang dimiliki, khususnya sumber pembiayaan dapat dialokasikan secara tepat.

Untuk mewujudkan hal tersebut perlu adanya perencanaan yang baik dan optimal dalam memanfaatkan sumber daya yang dimiliki oleh Pemerintah Kota Malang. Perencanaan penanganan kawasan permukiman kumuh perlu disusun secara komprehensif, mempertimbangkan berbagai aspek yang terkait, sehingga penanganan kawasan permukiman kumuh dapat berjalan efektif, tepat sasaran, sesuai kebutuhan penanganan dan memberikan manfaat bagi masyarakat.

\section{Teori}

\subsection{Perencanaan}

Perencanaan didefinisikan sebagai proses terus menerus yang melibatkan keputusan, atau pilihan, tentang cara-cara alternatif menggunakan sumber daya yang tersedia, dengan tujuan untuk mencapai tujuan tertentu pada suatu waktu di masa depan.

Definisi lain dan fungsi perencanaan adalah sebagai berikut:

1) Perencanaan dalam arti seluas-luasnya tidak lain adalah suatu proses mempersiapkan secara sistematis 
kegiatan-kegiatan yang akan dilakukan untuk mencapai sesuatu tujuan tertentu. Oleh karena itu pada hakekatnya terdapat pada tiap jenis usaha manusia.

2) Perencanaan adalah suatu cara bagaimana mencapai tujuan sebaik-baiknya (maximum output) dengan dengan sumber-sumber yang ada supaya lebih efisien dan efektif.

3) Perencanaan adalah penentuan tujuan yang akan dicapai atau yang akan dilakukan, bagaimana, bilamana dan oleh siapa.

Menurut Undang-Undang Nomor 25 Tahun 2004 tentang Sistem Perencanaan Pembangunan Nasional Pasal 1 ayat 1 , perencanaan adalah proses untuk menentukan tindakan masa depan yang tepat, melalui urutan pilihan dengan memperhitungkan sumber daya yang tersedia.

\subsection{Permukiman Kumuh}

Permukiman kumuh adalah suatu kawasan dengan bentuk hunian yang tidak berstruktur, tidak berpola (misalnya letak rumah dan jalannya tidak beraturan, tidak tersedianya fasilitas umum, prasarana dan sarana air bersih, MCK) bentuk fisiknya yang tidak layak misalnya secara reguler tiap tahun kebanjiran.

Menurut Undang-Undang Nomor 1 Tahun 2011 tentang Perumahan dan Kawasan Permukiman, definisi permukiman kumuh adalah permukiman yang tidak layak huni karena ketidakaturan bangunan, tingkat kepadatan bangunan yang tinggi, dan kualitas bangunan serta sarana dan prasarana yang tidak memenuhi syarat.

Berdasarkan pada karakter fisik dan aspek legalitasnya, klasifikasi permukiman kumuh ada dua jenis yaitu:

1) Kategori Slum, yaitu kawasan kumuh tetapi diakui sah sebagai daerah permukiman;

2) Kategori Squatter Settlement, yaitu pemukiman kumuh liar, yang menempati lahan yang tidak ditetapkan untuk kawasan hunian, misalnya: di sepanjang pinggir rel kereta api, di pinggir kali, di kolong jembatan, di pasar, di kuburan, di tempat pembuangan sampah, dan lainnya. Dari segi legalitasnya, kategori perrnukiman liar (squatter) ini umumnya menempati lahan yang bukan dalam hak penguasaannya misalnya pada lahan kosong yang ditinggal pemiliknya atau pada lahan kosong milik negara. Menurut Direktorat Jenderal Cipta Karya Kementerian Pekerjaan Umum, penanganan kawasan permukiman kumuh dapat dibagi menjadi tiga yaitu:

a) Pemugaran, dilakukan dengan melakukan perbaikan dan/ atau pembangunan kembali prasarana, sarana dan/ atau utilitas umum agar dapat berfungsi dengan optimal, untuk mewujudkan kawasan permukiman yang sehat dan layak huni.

b) Peremajaan, dilakukan dengan melakukan penataan kembali secara menyeluruh, termasuk pembangunan baru prasarana, sarana dan/ atau utilitas umum untuk mewujudkan kawasan permukiman yang sehat dan layak huni.

c) Pemukiman kembali, dilakukan dengan melakukan relokasi/ pemindahan secara menyeluruh terhadap masyarakat pada kawasan permukiman kumuh yang menempati kawasan yang peruntukannya bukan sebagai kawasan permukiman, ke lokasi baru untuk mewujudkan kawasan permukiman yang sehat dan layak huni.

\subsection{Infrastruktur}

Infrastruktur (perkotaan) adalah bangunan atau fasilitas-fasilitas dasar, peralatan-peralatan, instalasiinstalasi yang dibangun dan dibutuhkan untuk mendukung berfungsinya suatu sistem tatanan kehidupan sosial ekonomi masyarakat. Infrastruktur merupakan aset fisik yang dirancang dalam sistem sehingga mampu memberikan pelayanan prima pada masyarakat.

Elemen dasar lingkungan perumahan menurut Direktorat Jenderal Cipta Karya Kementerian Pekerjaan Umum, secara garis besar dapat dikelompokkan dalam infrastruktur fisik, antara lain:

1) Jaringan Jalan

Jalan merupakan prasarana transportasi darat yang meliputi bagian jalan termasuk bangunan pelengkap dan perlengkapannya yang diperuntukkan bagi lalu lintas, yang berada pada permukaan tanah, di atas permukaan tanah, di bawah permukaan tanah atau air serta di atas permukaan air.

2) Sistem Drainase

Sistem drainase dapat didefinisikan sebagai serangkaian bangunan air yang berfungsi untuk mengurangi dan/ atau membuang kelebihan air dari suatu kawasan atau lahan, sehingga lahan dapat difungsikan secara optimal.

3) Jaringan Air Bersih

Mengingat betapa pentingnya air bersih untuk kebutuhan manusia, maka kualitas air tersebut harus memenuhi persyaratan, yaitu:

a. Syarat fisik: air harus bersih dan tidak keruh, tidak berwarna, tidak berbau dan tidak berasa, suhu antara $10^{\circ}-25^{\circ} \mathrm{C}$ (sejuk).

b. Syarat kimiawi: tidak mengandung bahan kimiawi yang mengandung racun, tidak mengandung zatzat kimiawi yang berlebihan, cukup yodium, $\mathrm{pH}$ air antara 6,5-9,2 39 . 
c. Syarat bakteriologi: tidak mengandung kumankuman penyakit seperti disentri, kolera dan bakteri patogen penyebab penyakit.

4) Pengelolaan Sampah

Sampah adalah limbah yang bersifat padat yang berasal dari zat organik dan anorganik yang dianggap tidak berguna lagi dan harus dikelola agar tidak menganggu lingkungan.

5) Pengolahan Air Limbah

Kriteria air limbah domestik yang berasal dari pusat permukiman dan non permukiman antara lain:

a. Air mandi, air cucian, air dapur merupakan air limbah grey water; dan

b. Air jamban/ water closet (WC) merupakan air limbah black water.

\subsection{Manajemen Strategi}

Manajemen strategi pada sektor publik mengarahkan organisasi sektor publik untuk melakukan perencanaan manajemen dengan mempertimbangkan dengan baik faktor - faktor pendukung dan penghambat dalam organisasi. Salah satu metode yang dapat digunakan dalam manajemen strategis adalah analisis SWOT. Analisis SWOT berusaha untuk menganalisis faktor pendukung dan penghambat yang ada dalam organisasi kemudian berusaha menerjemahkannya ke dalam suatu strategi utama untuk mencapai visi, misi dan tujuan organisasi. Analisis SWOT adalah suatu identifikasi faktor strategis secara sistematis untuk merumuskan strategi. Strategi sendiri merupakan perencanaan induk yang komprehensif yang menjelaskan bagaimana mencapai semua tujuan yang telah ditetapkan sebelumnya. Kegiatan yang paling penting dalam proses analisis SWOT adalah memahami seluruh informasi dalam suatu kasus, menganalisis situasi untuk mengetahui isu apa yang sedang terjadi dan memutuskan tindakan apa yang harus segera dilakukan utuk memecahkan masalah.

Berdasarkan latar belakang diatas, maka penelitian ini bertujuan untuk: (1) melakukan identifikasi karakteristik kawasan permukiman kumuh yang ada di Kota Malang; (2) menentukan kawasan permukiman kumuh yang menjadi prioritas untuk peningkatan kualitas infrastruktur kawasan permukiman kumuh di Kota Malang; dan (3) menyusun strategi peningkatan kualitas infrastruktur pada kawasan permukiman kumuh di Kota Malang.

\section{Metode Penelitian}

Berdasarkan tujuan dari penelitian ini, yaitu untuk mengetahui karakteristik kawasan permukiman kumuh serta untuk menentukan kawasan permukiman kumuh prioritas dan menyusun strategi peningkatan kualitas infrastruktur pada kawasan permukiman kumuh di Kota Malang, maka jenis penelitian yang sesuai adalah penelitian survei, dimana informasi dikumpulkan dari responden dengan menggunakan kuesioner sebagai alat pengumpulan data.

Analisis data pada penelitian ini menggunakan metode kuantitatif untuk mengukur kondisi kekumuhan dan menentukan kawasan prioritas pada kawasan permukiman kumuh, berdasarkan Pedoman Peningkatan Kualitas Terhadap Perumahan Kumuh dan Permukiman Kumuh oleh Direktorat Pengembangan Permukiman Direktorat Jenderal Cipta Karya Kementerian Pekerjaan Umum. Selain itu dilakukan juga analisis SWOT untuk menyusun strategi peningkatan kualitas infrastruktur pada kawasan permukiman kumuh di Kota Malang.

Variabel infrastruktur pada kawasan permukiman kumuh yang diukur dalam penelitian ini meliputi: (1) Kondisi jalan lingkungan; (2) Kondisi penyediaan air minum; (3) Kondisi drainase lingkungan; (4) Kondisi pengelolaan air limbah; (5) Kondisi pengelolaan sampah; dan (6) Kondisi proteksi kebakaran.

Adapun metode pengumpulan data dalam penelitian ini dilakukan sebagai berikut: (1) metode angket atau kuesioner; (2) metode observasi; dan (3) metode dokumentasi. Responden dalam penelitian ini ditentukan dengan teknik purposive sampling. Responden dalam penelitian ini adalah pengurus Badan Keswadayaan Masyarakat (BKM) Kelurahan pada lokasi kawasan permukiman kumuh. Selain responden juga menggunakan informan dalam pengumpulan informasi dengan metode wawancara dengan unsur dari Badan Perencanaan Pembangunan Daerah Pemerintah Kota Malang terkait dengan perencanaan peningkatan kualitas infrastruktur pada kawasan permukiman kumuh. Informasi ini nantinya akan digunakan dalam penyusunan strategi peningkatan kualitas infrastruktur pada kawasan permukiman kumuh dengan metode analisis SWOT.

\section{Hasil Penelitian dan Pembahasan}

\subsection{Hasil Penelitian}

Identifikasi kondisi kekumuhan pada kawasan permukiman kumuh di kelurahan-kelurahan yang menjadi objek penelitian dilakukan dengan memberikan penilaian (scoring) pada variabel, indikator dan item yang telah ditentukan sebelumnya, yaitu pada Infrastruktur yang meliputi: (1) kondisi Jalan Lingkungan; (2) kondisi Penyediaan Air Minum; (3) kondisi Drainase Lingkungan;(4) kondisi Pengelolaan Air Limbah; (5) Kondisi Pengelolaan Sampah; dan (6) Kondisi Proteksi Kebakaran. Sedangkan variabel Status Lahan dan variabel Kepadatan Penduduk dinilai dari hasil pengumpulan data dilapangan serta data sekunder. 
Penilaian pada masing-masing item infrastruktur menggunakan rentang nilai/skor dengan perbedaan yang besar, yaitu nilai 5, 3, dan 1 . Hal ini dilakukan agar pada nilai kekumuhan yang diperoleh, terdapat perbedaan yang jelas antara kondisi kekumuhan dengan kategori kawasan kumuh berat, kawasan kumuh sedang dan kawasan kumuh ringan. Sedangkan makna dari masingmasing nilai tersebut adalah:

a. Nilai 5 mewakili kondisi yang sangat buruk pada item yang dinilai, dengan prosentase parameter kondisi/ tingkat pelayanan pada rentang 76\%-100\%.

b. Nilai 3 mewakili kondisi yang cukup buruk pada item yang dinilai, dengan prosentase parameter kondisi/ tingkat pelayanan pada rentang 51\%-75\%.

c. Nilai 1 mewakili kondisi yang buruk pada item yang dinilai, dengan prosentase parameter kondisi/ tingkat pelayanan pada rentang $25 \%-50 \%$.

Penilaian dari responden pada masing-masing item dijumlahkan, sehingga diketahui total nilai pada masingmasing indikator, dan nilai pada masing-masing indikator juga dijumlahkan sehingga diketahui nilai pada masingmasing variabel. Dari nilai pada masing-masing variabel, dijumlahkan kembali sehingga diperoleh total nilai yang menunjukkan kondisi kekumuhan pada kawasan permukiman kumuh tersebut. sedang berjumlah 13 kelurahan, yaitu: Kelurahan Penanggungan, Mergosono, Bandulan, Kotalama, Orooro Dowo, Ciptomulyo, Samaan, Jodipan, Polehan, Tulusrejo, Sukoharjo, Kiduldalem dan Kasin. Sedangkan kelurahan yang termasuk kedalam kategori kumuh ringan berjumlah 4 kelurahan, yaitu: Kelurahan Gadingkasri, Lowokwaru, Sukun dan Sumbersari.

Langkah selanjutnya adalah melakukan pengelompokan berdasarkan kondisi kekumuhannya, kejelasan status lahan dan tingkat kepadatan penduduk. Pengelompokan dilakukan dengan meletakkan kelurahan dengan nilai kondisi kekumuhan paling tinggi, dengan nilai status lahan paling tinggi, dan kepadatan penduduk paling tinggi pada kolom paling kiri, demikian seterusnya. Setelah diperoleh hasil pengelompokannya, kemudian dilakukan pengklasifikasian kawasan permukiman kumuh yang ada. Untuk lebih jelasnya dapat dilihat pada tabel 1 .

Berdasarkan hasil klasifikasi kawasan permukiman kumuh pada tabel 1, diketahui terdapat sebelas (11) klasifikasi kawasan permukiman kumuh, dengan klasifikasi sebagai berikut:

a) Klasifikasi 1, yaitu kelurahan dengan kondisi kumuh berat, dengan status lahan sebagian besar tidak jelas (ilegal), dengan tingkat kepadatan penduduk sedang.

Tabel 1 Penilaian kondisi kekumuhan pada kawasan permukiman kumuh

\begin{tabular}{|l|l|c|c|c|c|c|c|c|c|c|c|c|c|c|c|c|c|c|c|c|}
\hline NO & \multicolumn{1}{|c|}{ VARIABEL } & Jo & Po & $\mathbf{S a}$ & $\mathbf{P e}$ & $\mathbf{O r}$ & $\mathbf{G d}$ & $\mathbf{B r}$ & $\mathbf{K d}$ & $\mathbf{K s}$ & $\mathbf{S h}$ & $\mathbf{K o}$ & $\mathbf{M e}$ & $\mathbf{T u}$ & $\mathbf{S b}$ & $\mathbf{L o}$ & $\mathbf{C p}$ & $\mathbf{S k}$ & $\mathbf{T j}$ & $\mathbf{B d}$ \\
\hline A & Infrastruktur Dasar & & & & & & & & & & & & & & & & & & & \\
\hline 1 & Kondisi Jalan Lingkungan & 4 & 4 & 2 & 4 & 4 & 2 & 4 & 4 & 4 & 4 & 6 & 8 & 6 & 2 & 6 & 6 & 4 & 8 & 6 \\
\hline 2 & Kondisi Penyediaan Air Minum & 2 & 2 & 2 & 2 & 2 & 2 & 2 & 2 & 2 & 2 & 4 & 2 & 4 & 2 & 2 & 4 & 2 & 4 & 2 \\
\hline 3 & Kondisi Drainase Lingkungan & 9 & 11 & 13 & 19 & 13 & 11 & 19 & 11 & 13 & 9 & 11 & 13 & 13 & 7 & 9 & 11 & 9 & 15 & 13 \\
\hline 4 & Kondisi Pengelolaan Air Limbah & 8 & 8 & 6 & 6 & 8 & 6 & 10 & 8 & 6 & 6 & 8 & 8 & 8 & 6 & 2 & 6 & 6 & 10 & 8 \\
\hline 5 & Kondisi Pengelolaan Sampah & 9 & 7 & 7 & 7 & 7 & 3 & 9 & 7 & 5 & 7 & 5 & 7 & 3 & 3 & 3 & 5 & 3 & 9 & 9 \\
\hline 6 & Kondisi Proteksi Kebakaran & 8 & 8 & 10 & 10 & 10 & 8 & 8 & 6 & 6 & 10 & 10 & 10 & 6 & 8 & 10 & 10 & 8 & 10 & 10 \\
\hline & Nilai Kondisi Kekumuhan & $\mathbf{4 0}$ & $\mathbf{4 0}$ & $\mathbf{4 0}$ & $\mathbf{4 8}$ & $\mathbf{4 4}$ & $\mathbf{3 2}$ & $\mathbf{5 2}$ & $\mathbf{3 8}$ & $\mathbf{3 6}$ & $\mathbf{3 8}$ & $\mathbf{4 4}$ & $\mathbf{4 8}$ & $\mathbf{4 0}$ & $\mathbf{2 8}$ & $\mathbf{3 2}$ & $\mathbf{4 2}$ & $\mathbf{3 2}$ & $\mathbf{5 6}$ & $\mathbf{4 8}$ \\
\hline $\mathbf{B}$ & Status Lahan & $\mathbf{5}$ & $\mathbf{3}$ & $\mathbf{5}$ & $\mathbf{3}$ & $\mathbf{5}$ & $\mathbf{1}$ & $\mathbf{5}$ & $\mathbf{3}$ & $\mathbf{3}$ & $\mathbf{1}$ & $\mathbf{5}$ & $\mathbf{3}$ & $\mathbf{1}$ & $\mathbf{1}$ & $\mathbf{1}$ & $\mathbf{3}$ & $\mathbf{1}$ & $\mathbf{5}$ & $\mathbf{3}$ \\
\hline $\mathbf{C}$ & Kepadatan Penduduk & $\mathbf{1}$ & $\mathbf{1}$ & $\mathbf{3}$ & $\mathbf{5}$ & $\mathbf{1}$ & $\mathbf{3}$ & $\mathbf{3}$ & $\mathbf{1}$ & $\mathbf{1}$ & $\mathbf{5}$ & $\mathbf{3}$ & $\mathbf{3}$ & $\mathbf{1}$ & $\mathbf{1}$ & $\mathbf{1}$ & $\mathbf{1}$ & $\mathbf{1}$ & $\mathbf{1}$ & $\mathbf{1}$ \\
\hline
\end{tabular}

Keterangan : hasil rekapitulasi kuesioner, 2015

\begin{tabular}{|c|c|c|c|c|c|c|c|}
\hline Jo & Kel. Jodipan & Gd & Kel. Gadingkasri & Ko & Kel. Kotalama & Cp & Kel. Ciptomulyo \\
\hline Po & Kel. Polehan & $\mathrm{Br}$ & Kel. Bareng & $\mathrm{Me}$ & Kel. Mergosono & Sk & Kel. Sukun \\
\hline Sa & Kel. Samaan & Kd & Kel. Kiduldalem & Tu & Kel. Tulusrejo & $\mathrm{Tj}$ & Kel.Tanjungrejo \\
\hline $\mathrm{Pe}$ & Kel. Penanggungan & Ks & Kel. Kasin & $\mathrm{Sb}$ & Kel. Sumbersari & $\mathrm{Bd}$ & Kel. Bandulan \\
\hline Or & Kel.Oro-oro Dowo & Sh & Kel. Sukoharjo & Lo & Kel. Lowokwaru & & \\
\hline
\end{tabular}

$\begin{array}{lll}: & \text { Kumuh Berat } & (>51) \\ : & \text { Kumuh Sedang } & (36-50) \\ : & \text { Kumuh Ringan } & (20-35)\end{array}$

Berdasarkan hasil pengisian kuesioner dan didukung oleh hasil wawancara terhadap responden, serta pengamatan lapangan, maka dapat diketahui kondisi kekumuhan pada masing-masing kelurahan yang menjadi objek penelitian ini.

Dari Tabel 1 dapat diketahui bahwa kelurahan yang termasuk kedalam kategori kumuh berat ada 2 kelurahan, yaitu: Kelurahan Tanjungrejo dan Kelurahan Bareng. Adapun kelurahan yang termasuk dalam kategori kumuh
Yang termasuk dalam klasifikasi ini adalah Kelurahan Bareng.

b) Klasifikasi 2, yaitu kelurahan dengan kondisi kumuh berat, dengan status lahan sebagian besar tidak jelas (ilegal), dengan tingkat kepadatan penduduk rendah. Yang termasuk dalam klasifikasi ini adalah Kelurahan Tanjungrejo.

c) Klasifikasi 3, yaitu kelurahan dengan kondisi kumuh sedang, dengan status lahan sebagian besar tidak jelas 
(ilegal), dengan tingkat kepadatan penduduk sedang. Yang termasuk dalam klasifikasi ini adalah Kelurahan Kotalama dan Kelurahan Samaan.

d) Klasifikasi 4, yaitu kelurahan dengan kondisi kumuh sedang, dengan status lahan sebagian besar tidak jelas (ilegal), dengan tingkat kepadatan penduduk rendah. Yang termasuk dalam klasifikasi ini adalah Kelurahan Oro-oro Dowo dan Kelurahan Jodipan. i) Klasifikasi 9, yaitu kelurahan dengan kondisi kumuh sedang, dengan status lahan sebagian besar jelas (legal) dan tingkat kepadatan penduduk rendah. Yang termasuk dalam klasifikasi ini adalah Kelurahan Tulusrejo.

j) Klasifikasi 10, yaitu kelurahan dengan kondisi kumuh ringan, status lahan sebagian besar jelas (legal) dan tingkat kepadatan penduduk sedang. Yang termasuk

Tabel 2 Klasifikasi dan Penentuan Prioritas Peningkatan Kualitas Infrastruktur Pada Kawasan Permukiman Kumuh

\begin{tabular}{|c|c|c|c|c|c|c|c|c|c|c|c|c|c|c|c|c|c|c|c|c|}
\hline No & ASPEK & $\mathrm{Br}$ & Tj & Ko & Sa & Or & Jo & $\mathrm{Pe}$ & Me & Cp & Bd & Po & Kd & Ks & Sh & $\mathrm{Tu}$ & Gd & Lo & Sk & Sb \\
\hline \multirow[t]{4}{*}{ A } & \multicolumn{20}{|l|}{ Kondisi Kekumuhan } \\
\hline & Kumuh Berat & $\mathrm{x}$ & $\mathrm{x}$ & & & & & & & & & & & & & & & & & \\
\hline & Kumuh Sedang & & & $\mathrm{X}$ & $\mathrm{X}$ & $\mathrm{X}$ & $\mathrm{X}$ & $\mathrm{x}$ & $\mathrm{X}$ & $\mathrm{x}$ & $\mathrm{X}$ & $\mathrm{X}$ & $\mathrm{X}$ & $\mathrm{x}$ & $\mathrm{X}$ & $\mathrm{X}$ & & & & \\
\hline & Kumuh Ringan & & & & & & & & & & & & & & & & $\mathrm{X}$ & $\mathrm{X}$ & $\mathrm{X}$ & $\mathrm{x}$ \\
\hline \multirow[t]{4}{*}{ B } & \multicolumn{20}{|l|}{ Status Lahan } \\
\hline & Sebagian besar tidak jelas (ilegal) & $\mathrm{x}$ & $\mathrm{x}$ & $\mathrm{x}$ & $\mathrm{x}$ & $\mathrm{x}$ & $\mathrm{x}$ & & & & & & & & & & & & & \\
\hline & Sebagian jelas, sebagian tidak jelas & & & & & & & $\mathrm{x}$ & $x$ & $\mathrm{x}$ & $\mathrm{x}$ & $x$ & $\mathrm{x}$ & $\mathrm{x}$ & & & & & & \\
\hline & Sebagian besar jelas (legal) & & & & & & & & & & & & & & $\mathrm{x}$ & $\mathrm{x}$ & $\mathrm{x}$ & $\mathrm{x}$ & $\mathrm{x}$ & $\mathrm{x}$ \\
\hline C & \multicolumn{20}{|l|}{ Kepadatan Penduduk } \\
\hline & Kepadatan Tinggi & & & & & & & $\mathrm{x}$ & & & & & & & $\mathrm{x}$ & & & & & \\
\hline & Kepadatan Sedang & $\mathrm{x}$ & & $\mathrm{x}$ & $\mathrm{x}$ & & & & $\mathrm{x}$ & & & & & & & & $\mathrm{x}$ & & & \\
\hline & Kepadatan Rendah & & $\mathrm{x}$ & & & $\mathrm{x}$ & $\mathrm{x}$ & & & $\mathrm{x}$ & $x$ & $\mathrm{x}$ & $\mathrm{x}$ & $\mathrm{x}$ & & $x$ & & $x$ & $\mathrm{x}$ & $x$ \\
\hline \multicolumn{2}{|c|}{ KLASIFIKASI } & 1 & 2 & 3 & 3 & 4 & 4 & 5 & 6 & 7 & 7 & 7 & 7 & 7 & 8 & 9 & 10 & 11 & 11 & 11 \\
\hline \multicolumn{2}{|c|}{ SKALA PRIORITAS PENANGANAN } & 1 & 1 & 2 & 2 & 2 & 2 & 3 & 3 & 3 & 3 & 3 & 3 & 3 & 4 & 4 & 5 & 5 & 5 & 5 \\
\hline
\end{tabular}

Keterangan

\begin{tabular}{|lll|lll|lll|lll|}
\hline $\mathrm{Br}$ & $:$ & Kel. Bareng & Ko & $:$ & Kel. Kotalama & $\mathrm{Po}$ & $:$ Kel. Polehan & Gd & $:$ & Kel. Gadingkasri \\
\hline $\mathrm{Tj}$ & $:$ & Kel. Tanjungrejo & $\mathrm{Or}$ & $:$ & Kel. Oro-oro Dowo & $\mathrm{Tu}$ & $:$ & Kel. Tulusrejo & Lo & $:$ & Kel. Lowokwaru \\
\hline $\mathrm{Pe}$ & $:$ & Kel. Penanggungan & $\mathrm{Cp}$ & $:$ & Kel. Ciptomulyo & $\mathrm{Sh}$ & $:$ & Kel. Sukoharjo & $\mathrm{Sk}$ & $:$ & Kel. Sukun \\
\hline $\mathrm{Me}$ & $:$ & Kel. Mergosono & $\mathrm{Sa}$ & $:$ & Kel. Samaan & $\mathrm{Kd}$ & $:$ & Kel. Kiduldalem & $\mathrm{Sb}$ & $:$ & Kel. Sumbersari \\
\hline $\mathrm{Bd}$ & $:$ & Kel. Bandulan & $\mathrm{Jo}$ & $:$ & Kel. Jodipan & $\mathrm{Ks}$ & $:$ & Kel. Kasin & & &
\end{tabular}

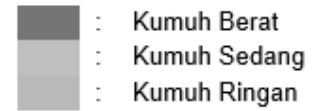

Kumuh Ringan e) Klasifikasi 5, yaitu kelurahan dengan kondisi kumuh sedang, dengan status lahan sebagian jelas (legal) dan sebagian lainnya tidak jelas (ilegal), dengan tingkat kepadatan penduduk tinggi. Yang termasuk dalam klasifikasi ini adalah Kelurahan Penanggungan.

f) Klasifikasi 6, yaitu kelurahan dengan kondisi kumuh sedang, dengan status lahan sebagian jelas (legal) dan sebagian lainnya tidak jelas (ilegal), dengan tingkat kepadatan penduduk sedang. Yang termasuk dalam klasifikasi ini adalah Kelurahan Mergosono.

g) Klasifikasi 7, yaitu kelurahan dengan kondisi kumuh sedang, dengan status lahan sebagian jelas (legal) dan sebagian lainnya tidak jelas (ilegal), dengan tingkat kepadatan penduduk rendah. Yang termasuk dalam klasifikasi ini adalah Kelurahan Ciptomulyo, Bandulan, Polehan, Kiduldalem dan Kelurahan Kasin.

h) Klasifikasi 8, yaitu kelurahan dengan kondisi kumuh sedang, dengan status lahan sebagian besar jelas (legal) dan dengan tingkat kepadatan penduduk tinggi. Yang termasuk dalam klasifikasi ini adalah Kelurahan Sukoharjo. dalam klasifikasi ini adalah Kelurahan Gadingkasri.

k) Klasifikasi 11, yaitu kelurahan dengan kondisi kumuh ringan, status lahan sebagian besar jelas (legal), dan tingkat kepadatan penduduk rendah. Yang termasuk dalam klasifikasi ini adalah Kelurahan Lowokwaru, Sukun dan Kelurahan Sumbersari.

Sebagaimana yang dinyatakan oleh Tjokroamidjodjo (1986), bahwa perencanaan merupakan hal yang penting, karena terdapatnya suatu pengarahan dan pedoman dalam pelaksanaan kegiatan. Selain itu melalui perencanaan yang baik dapat disusun suatu prioritas, sehingga sumber daya yang dimiliki dapat dikelola dengan baik, tujuan yang diinginkan dapat tercapai dan memperoleh manfaat yang optimal.

Dari hasil analisis pada tabel 2 diatas, disusun prioritas peningkatan kualitas infrastruktur pada kawasan permukiman kumuh sebagai berikut:

1) Prioritas 1 untuk kelurahan klasifikasi 1 dan 2, yaitu Kelurahan Bareng dan Kelurahan Tanjungrejo. 
2) Prioritas 2 untuk kelurahan klasifikasi 3 dan 4, yaitu Kelurahan Kotalama, Samaan, Oro-oro Dowo dan Kelurahan Jodipan.

3) Prioritas 3 untuk kelurahan klasifikasi 5,6 dan 7, yaitu Kelurahan Penanggungan, Mergosono, Ciptomulyo, Bandulan, Polehan, Kiduldalem dan Kelurahan Kasin.

4) Prioritas 4 untuk kelurahan klasifikasi 8 dan 9, yaitu Kelurahan Sukoharjo dan Kelurahan Tulusrejo.

5) Prioritas 5 untuk kelurahan klasifikasi 10 dan 11, yaitu Kelurahan Gadingkasri, Lowokwaru, Sukun dan Kelurahan Sumbersari.

Dalam menentukan pola penanganan peningkatan kualitas infrastruktur pada kawasan permukiman kumuh, selain kondisi kekumuhan pada kawasan tersebut, hal yang menjadi pertimbangan utama adalah kejelasan status lahan. Hal ini didasarkan bahwa pada kawasan yang peruntukannya bukan sebagai kawasan permukiman; misalnya kawasan sempadan sungai, sempadan rel kereta api, atau tanah milik negara; maka peningkatan kualitas infrastrukturnya tidak bisa menggunakan pola pemugaran dan peremajaan, karena tidak sesuai dengan peruntukan dan fungsi utama kawasan tersebut. Pada kawasan permukiman kumuh tesebut diupayakan untuk dilakukan pola pemukiman kembali/ relokasi bagi masyarakat pada kawasan tersebut.

Berikut ini rekomendasi pola penanganan peningkatan kualitas infrastruktur kawasan permukiman kumuh pada masing-masing kawasan prioritas:

1) Kawasan Prioritas 1, yaitu Kelurahan Bareng dan Kelurahan Tanjungrejo, pola penanganan untuk kawasan prioritas ini adalah dengan pola pemukiman kembali atau relokasi.

2) Kawasan Prioritas 2, yaitu Kelurahan Kelurahan Kotalama, Samaan, Oro-oro Dowo dan Kelurahan Jodipan, pola penanganan untuk kawasan ini adalah dengan pola pemukiman kembali atau relokasi.

3) Kawasan Prioritas 3, yaitu Kelurahan Penanggungan, Mergosono, Ciptomulyo, Bandulan, Polehan, Kiduldalem dan Kelurahan Kasin, pola penanganan untuk kawasan ini adalah:

a. Pada kawasan dengan status lahan yang jelas (legal), dilakukan dengan pola pemugaran untuk kawasan dengan tingkat kepadatan penduduk tinggi dan sedang dan pola peremajaan untuk kawasan dengan tingkat kepadatan penduduk rendah.

b. Sedangkan pada kawasan dengan status lahan yang tidak jelas/ ilegal, dilakukan dengan pola pemukiman kembali/ relokasi.

4) Kawasan Prioritas 4, yaitu Kelurahan Sukoharjo dan Kelurahan Tulusrejo, pola penanganan untuk kawasan ini adalah dilakukan dengan pola pemugaran untuk kawasan dengan tingkat kepadatan penduduk tinggi dan pola peremajaan untuk kawasan dengan tingkat kepadatan penduduk rendah.

5) Kawasan Prioritas 5, yaitu Kelurahan Gadingkasri, Lowokwaru, Sukun dan Kelurahan Sumbersari, pola penanganan untuk kawasan ini adalah dilakukan dengan pola pemugaran untuk kawasan dengan tingkat kepadatan penduduk sedang dan pola peremajaan untuk kawasan dengan tingkat kepadatan penduduk rendah.

Strategi penanganan disusun berdasarkan analisis faktor internal dan eksternal dalam peningkatan kualitas infrastruktur pada kawasan permukiman kumuh, sehingga perlu diketahui faktor-faktor internal (kekuatan dan kelemahan) dan faktor-faktor eksternal (peluang dan ancaman). Dari hasil wawancara dengan responden kuesioner, yaitu pengurus BKM Kelurahan, dan dengan unsur Bappeda Kota Malang disusun dan dikelompokkan faktor-faktor yang menjadi kekuatan dan kelemahan (faktor internal) serta faktor-faktor yang menjadi peluang dan ancaman (faktor eksternal) sebagai berikut:

Tabel 3 Faktor-faktor internal dan eksternal dalam

peningkatan kualitas infrastruktur pada kawasan permukiman kumuh

\section{FAKTOR INTERNAL}

\section{No. Kekuatan}

1 Komitmen kuat dari pemerintah daerah untuk menangani kawasan kumuh

2 Peran aktif masyarakat tinggi yang tinggi

3 Anggaran bidang infrastruktur besar

4 Adanya peraturan daerah yang mendukung penanganan kawasan kumuh

\section{No. Kelemahan}

1 Perencanaan penanganan kawasan kumuh yang komprehensif belum ada

2 Penanganan yang telah dilakukan oleh pemerintah daerah kurang efektif

3 Pemerintah daerah kurang antisipasi dalam perkembangan kawasan kumuh

4 Pengetahuan dan kesadaran masyarakat kurang tentang kesehatan lingkungan

5 Pengetahuan dan kesadaran masyarakat kurang tentang tata ruang kota

\section{FAKTOR EKSTERNAL}

\section{No. Peluang}

1 Alokasi anggaran dari pemerintah pusat dan provinsi untuk penanganan kawasan kumuh cukup besar dan beragam

2 Peningkatan sinergi dengan instansi terkait dalam pengelolaan kawasan sempadan dan bantaran

3 Kerjasama dengan sektor privat/ swasta (program CSR) untuk peningkatan kualitas infrastruktur pada kawasan permukiman kumuh 


\section{FAKTOR INTERNAL}

\section{No. Kekuatan}

No. Ancaman

1 Penurunan kualitas lingkungan pada kawasan permukiman kumuh

2 Adanya penolakan dari masyarakat pada kawasan kumuh untuk direlokasi

Keterangan: Hasil penelitian, 2015

Dari faktor-faktor internal dan eksternal yang diperoleh, selanjutnya disusun pada Matriks Interaksi IFAS-EFAS SWOT untuk mengetahui menyusun strategi perencanaan peningkatan kualitas infrastruktur pada kawasan permukiman kumuh berdasarkan keterkaitan antar faktor-faktor internal dan eksternal tersebut. Dari hasil analisis Matriks Interaksi IFAS-EFAS SWOT diperoleh hasil sebagai berikut:

A. Strategi SO

1) Meningkatkan koordinasi dan sinkronisasi program dan kegiatan dengan pemerintah pusat maupun pemerintah provinsi (S1, S3, O1).

2) Mengupayakan kerjasama dengan serta sektor swasta melalui program CSR (S1, S3, O1, O3).

3) Menjembatani serta memfasilitasi program dan kegiatan dari pemerintah pusat yang diberikan langsung kepada masyarakat (S2, O1).

4) Meningkatkan koordinasi dan sinergi dengan instansi terkait dalam penanganan dan penataan pada kawasan sempadan dan bantaran (S4, S5, $\mathrm{O} 2)$.

B. Strategi WO

1) Menyusun perencanaan penanganan kawasan permukiman kumuh secara komprehensif (W2, $\mathrm{W} 3, \mathrm{O} 1, \mathrm{O} 3$ ).

2) Menyusun perencanaan penanganan kawasan permukiman kumuh, yang terkait penataan dan pengelolaan kawasan sempadan dan bantaran (W1, $\mathrm{W} 2, \mathrm{~W} 4, \mathrm{O} 2$ ).

\section{Strategi ST}

1) Menyusun prioritas dalam perencanaan peningkatan kualitas infrastruktur pada kawasan permukiman kumuh dengan memperhatikan daya dukung lingkungan serta melibatkan masyarakat (S1, S2, S3, S4, T1).

2) Meningkatkan sosialisasi kepada masyarakat pada kawasan permukiman kumuh (S5, T2).

D. Strategi WT

1) Menyusun perencanaan peningkatan kualitas infrastruktur kawasan permukiman kumuh yang berwawasan lingkungan (W1, W2, W3, T1).

2) Meningkatkan sosialisasi dalam upaya peningkatan pemahaman dan kesadaran bagi masyarakat pada kawasan permukiman kumuh (W4, T2).
Dalam implementasinya strategi-strategi tersebut akan lebih baik dan memberikan dampak yang optimal dalam upaya peningkatan infrastruktur pada kawasan permukiman kumuh, jika dalam pelaksanaannya bisa dijalankan secara simultan dan berkelanjutan. Secara umum, prioritas dari strategi-strategi tersebut adalah penyusunan rencana yang komprehensif dalam peningkatan kualitas infrastruktur pada kawasan permukiman kumuh. Sebagaimana dinyatakan oleh Tjokroamidjodjo (1986), bahwa pentingnya suatu perencanaan adalah bahwa dengan adanya perencanaan terdapatnya suatu pengarahan kegiatan, adanya pedoman bagi pelaksanaan kegiatan-kegiatan yang ditujukan kepada pencapaian tujuan pembangunan. Selain itu dapat ditentukan pula alternatif terbaik atau kombinasi terbaik, serta menentukan prioritas, sehingga keberhasilan pembangunan dapat diukur dan dievaluasi. Namun, strategi-strategi yang lain juga merupakan prioritas yang harus dilaksanakan oleh Pemerintah Kota Malang untuk mencapai tujuan terciptanya kawasan permukiman yang sehat dan layak huni bagi masyarakat.

\section{Kesimpulan}

Berdasarkan hasil analisis yang telah dilakukan dalam penelitian tentang penentuan kawasan prioritas untuk peningkatan kualitas infrastruktur, diperoleh kesimpulan sebagai berikut:

a) Karakteristik kawasan permukiman kumuh berdasarkan hasil identifikasi yang dilakukan, terbagi ke dalam sebelas (11) klasifikasi kawasan permukiman kumuh. Klasifikasi ini muncul karena adanya persamaan dan perbedaan dari hasil penilaian kondisi kekumuhan serta status lahan dan kepadatan penduduk pada masing-masing lokasi kawasan permukiman kumuh.

b) Penentuan kawasan permukiman kumuh prioritas disusun berdasarkan hasil klasifikasi kawasan permukiman kumuh, dengan pertimbangan utama kondisi kekumuhan kawasan, pertimbangan status lahan dan kepadatan penduduk. Hasil dari penentuan kawasan prioritas pada lokasi penelitian diperoleh 5 (lima) kawasan prioritas.

c) Strategi yang direkomendasikan untuk peningkatan kualitas infrastruktur pada kawasan permukiman kumuh adalah sebagai berikut:

- Menyusun rencana peningkatan kualitas infrastruktur pada kawasan permukiman kumuh secara komprehensif; yang di dalamnya mencakup rencana program, kegiatan, tahapan pelaksanaan, hingga sumber pendanaan; yang disusun secara konsisten sampai tingkat Renstra SKPD terkait.

- Meningkatkan koordinasi dan sinkronisasi program dan kegiatan untuk peningkatan kualitas 
infrastruktur kawasan permukiman kumuh, baik dengan pemerintah pusat, pemerintah provinsi serta dengan masyarakat (BKM).

- Melibatkan masyarakat dalam proses penyusunan rencana peningkatan kualitas infrastruktur pada kawasan permukiman kumuh.

- Meningkatkan koordinasi dan sinergi dengan instansi terkait dalam pemanfaatan ruang wilayah kota pada kawasan sempadan dan bantaran.

- Meningkatkan sosialisasi dalam upaya peningkatan pemahaman dan kesadaran bagi masyarakat pada kawasan permukiman kumuh tentang pemanfaatan ruang wilayah dan pola-pola penanganan dan peningkatan kualitas infrastruktur kawasan permukiman kumuh.

- Mengupayakan peluang kerjasama dengan serta sektor privat/ swasta melalui program CSR untuk peningkatan kualitas infrastruktur permukiman kumuh.

Dari kesimpulan yang telah dikemukakan diatas, rekomendasi yang dapat diberikan untuk memperkuat dan menyempurnakan upaya peningkatan kualitas infrastruktur kawasan permukiman kumuh adalah sebagai berikut:

a) Pemerintah Kota Malang perlu segera menyusun perencanaan penanganan kawasan permukiman kumuh yang bersifat komprehensif/ menyeluruh.

b) Perencanaan peningkatan kualitas infrastruktur kawasan permukiman kumuh, merupakan bagian dari perencanaan penanganan kawasan permukiman kumuh, yang harus memperhatikan dan memiliki konsistensi terhadap perencanaan pada tingkatan diatasnya (RPJPD, RPJMD, RTRW, RDTR) maupun perencanaan pelaksanaannya (Renstra).

c) Koordinasi dan sinergi antara SKPD terkait perlu diarahkan dan difokuskan dalam penanganan kawasan permukiman kumuh, khususnya untuk peningkatan infrastruktur kawasan permukiman kumuh.

d) Pemerintah Kota Malang perlu mengoptimalkan peluang penanganan kawasan permukiman kumuh melalui kerjasama dengan pihak privat/ swasta.

e) Perlu ada upaya peningkatan pemahaman dan kesadaran bagi masyarakat terkait pentingnya kawasan permukiman yang sehat dan layak huni dan pemahaman tentang pemanfaatan ruang.

\section{Daftar Pustaka}

Bappeda Kota Malang. (2014). Rencana Pembangunan Menengah Daerah (RPJMD) Kota Malang Tahun 2013-2018. Malang: Bappeda Kota Malang.

Keputusan Walikota Malang Nomor 188.45/86/35.73.112/2015 tentang Penetapan Lingkungan Perumahan dan Permukiman Kumuh.
Peraturan Daerah Nomor 12 Tahun 2014 tentang Rencana Pembangunan dan Pengembangan Perumahan dan Kawasan Permukiman (RP3KP) Kota Malang.

Tjokroamidjojo, Bintoro. (1986). Perencanaan Pembangunan. Jakarta: PT Gunung Agung.

Undang - Undang No. 1 Tahun 2011 tentang Perumahan dan Kawasan Permukiman.

Undnag - Undang No 25 Tahun 2004 tentang Sistem Perencanaan Pembangunan Nasional. 